\title{
Strategic Leadership For The Implementation of Three Values of Higher Education Performed by The Indonesian Defense University (IDU) In The 2015-2018 Period
}

\author{
Ahmad Gafuri Dohamid \\ Universitas Negeri Jakarta \\ Email: ahmadgafuri_im12s3@mahasiswa.unj.ac.id \\ Ma'ruf Akbar \\ Universitas Negeri Jakarta \\ Email: maruf.akbar@unj.ac.id \\ Muchlis R. Luddin \\ Universitas Negeri Jakarta \\ Email: rantoni.luddin@unj.ac.id
}

\begin{abstract}
This research will discuss about IDU's management in strategic leadership to implement Three Values of Higher Education in the 2015-2018 period of time using qualitative method of research. The result obtained from the research shows that in educational aspect, IDU has taken necessary strategic steps for its improvement. IDU manages the resources that are owned by IDU in academic aspect. IDU has done management processes according to the vision and mission during their time of leadership. In research department, the strategic leadership of IDU is not conducted optimally, especially when using and keeping the core competency. In community service, IDU is not capable in creating an innovation for the community. It is also found in the research that the biggest challenge that IDU has is regarding human resources. Most of the lecturers teach in IDU do not have defense background in their previous education.
\end{abstract}

Keywords: Three Values of Higher Education, strategic leadership, higher education management, Indonesia Defense University.

Received: 15 November 2019 ;

Accepted: 5 March 2020 ;

Publish; June 2020.

\section{How to Cite:}

Dohamid, A.G., Akbar, M., \& Luddin, M.R. (2020). Strategic Leadership For The Implementation of Three Values of Higher Education Performed by The Indonesian Defense University (IDU) In The 2015-2018 Period. International Journal of Human Capital Management, 4 (1), 80-84. https://doi.org/10.21009/IJHCM.04.01.07 


\section{INTRODUCTION}

Higher education is an educational institution that plays an important role in nation building. Indonesian Law, Number 12, the year of 2012 concerning Higher Education states that one of the functions of higher education is to carry out the functions of Three Values of Higher Education. The implementation of Three Values of Higher Education will not be achieved optimally if the said implementation is not supported by a qualified higher education management. Furthermore, a qualified higher education management has to be supported by a strategic leadership of the university leader. IDU as one of the higher education institution also faces several challenges both in academic and non-academic aspects while implementing the Three Values of Higher Education.

The goal of the research is to find the answer of four research questions, as follows: (1) How is the strategic leadership in implementing Three Values of Higher Education in academic aspects, (2) How is the strategic leadership in implementing Three Values of Higher Education in research department, (3) How is the strategic leadership in implementing Three Values of Higher Education in community service, and (4) What are the obstacles faced in implementing Three Values of Higher Education performed by The Indonesia Defense University (IDU).

The novelty of this research as follows: (1) Focus of this study related to strategic leadership in the context of management for implementing Three Values of Higher Education by IDU has never been done before, (2) In analyzing the object of the study, this research is more complete and more comprehensive than previous studies, and (3) In this study, it was found that although IDU faces many obstacles, IDU continues to strive to achieve its vision as world class university by improving the quality of lecturers, students, and facilities.

\section{LITERATURE REVIEW}

This study uses six related theories to help analyze the problems and formulate the problem-solving in this research. The first theory that will be used in this study is management theory. Management is defined as a science and art in organizing to regulate others in an effort to achieve an organizational goal (Terry and Rue, 1992). According to Griffin (2015, p.1), the management process itself consists of planning, organizing, actuating, and controlling. Meanwhile, according to Malayu P. Hasibuan management can also be defined as the management of existing resources in an organization to achieve its goals, such as people, money, materials, machine, and market.

The second theory is higher education management theory. In this theory, the implementation of higher education refers to the existing national standards, namely national standards of education, national standards of academic research, and national standards of community service. This standards is already regulated in the Ministry Research, Technology, and Higher Education of the Republic of Indonesia regulation and apply to all universities in Indonesia, including IDU in implementing The Three Values of High Education. The third theory that will be used is organization theory. Based on the theory according to Hicks (1972, p.15), the organization consists of number of people who works and interacts with each other in an organizational structure that has a common goal, namely achieving the vision and mission of the organization.

The forth theory is nonprofit organization theory. Nonprofit organization is an organization whose purpose is not to take profit (Koteen in Salusu, 2015, p.15). Nonprofit organizations can include public services, such as schools, hospitals, and community assistance (Oleck in Salusu, 2015 , p.15). Like any other organizations, nonprofit organizations consist of a group of people who have a common goal. The fifth theory is leadership theory. Based on Yukl's definition, leadership is the art, ability and skills of a person or group who occupies a position as leader of a work unit in the form of a relationship or process to influence, convince, inspire and guide the 
behavior of others, especially followers or subordinates through the communication process (2009, p.9).

Overall leadership functions are setting goals, guiding, leading, giving or developing work motivation, driving an organization by structuring group structures, establishing good communication networks, building teams, creating unity, maintaining harmonious cooperative relationships, providing supervision or supervision and efficient evaluation, process control, delegation and delegation of authority and bringing followers to the intended target in accordance with the provisions of time and planning.

The last theory that will be used in this research is strategic leadership theory. Strategic leadership is the ability of a leader to communicate the vision of the organization and always inspire all members to keep going in line with that vision (Kotter, 1996, p.16). According to Slawinski (2007, p.297), a strategic leader must be able to anticipate environmental changes in the future and be flexible to changes to achieve organizational goals. A strategic leader must have several criteria for effective strategic leadership, namely the leader can determine the strategic direction, utilize and maintain core competencies, develop human resources, maintain an effective organizational culture, emphasize ethical practices, and create a balance of organizational control (Hitt et al., 2001, p.500). These six criteria will be used in this study.

\section{RESEARCH METHOD}

This study uses qualitative method and is analyzed by phenomenology study. Primary data sources used in this study come from research subjects (Bandur, 2016, p.18). The research subjects are people who are directly involved in primary data collection and are the resource persons in the interview activities. Determination of informants is done by finding key informants based on purposive sampling and to add depth to the data of researchers using snowball techniques (Arikunto, 2010, p.183).

\section{RESULT AND DISCUSSION}

Based on the findings in this study, it can be argued that IDU's strategic leadership in implementing The Three Values of High Education has not been effective. In the field of education itself, some lecturers at IDU still lack of mastery in the fields that being taught and their educational background is not linear. Lecturers at IDU are allowed to teach only limited to their experience in the field of defense. This is indeed because there are no doctors in defense science in Indonesia yet. Other than that, not all study programs at IDU have a Semester Learning Plans and teaching materials. Some of them only have power point, which cannot be used as a teaching reference. IDU itself has made EDOM (Student Evaluation of Lecturers) for evaluation, but this system is felt to be less effective by students because of the large number of lecturers who teach for only one course. As mentioned earlier, IDU also has not yet provided academic space to free lecturers and students to think critically.

Previously, there is no research that studies about the implementation of Three Values of High Education in IDU. But there is some previous research that studies about strategic leadership in management, such as a research written by Cagdas Emiroglu and Didem Ozer Caylan in 2014 about "The Importance Of Strategic Leadership For Port Management: A Delphi Research On Top Managers Of Turkish Private Port". Other than that, previous research that studies about strategic leadership in management is "The Importance Of Strategic Leadership In Healthcare Management", written by Fatih Budak and Ahmet Kar in 2014. The difference between this research and the previous research is in the research object.

IDU's strategic leadership in education continues to be improved in order to achieve IDU's organizational goals as a world class university. As explained earlier, many IDU lecturers are born from the military or even many of them are still very thick with their military style. From this phenomenon, arises a question how IDU's lecturers that comes from the military became humanists and academics. To answer this question, IDU continues to improve the quality of the 
human resources of the lecturers by sending them to school with the help of funds from IDU itself.

The strategic leadership undertaken by IDU in the field of education can also be seen from their decision to start PhD program in defense studies at IDU. This will certainly help IDU to maintain their core competencies and improve their quality, because IDU's lecturers' problems that are not linear can be resolved later. In addition, a strategic decision made by IDU to improve the quality of lecturers is by collaborating with other universities to organize Basic Instructional Engineering Skills Improvement (Peningkatan Keterampilan Dasar Teknik Instruksional/PEKERTI), which is a professionalism development training for beginner lecturers. For senior lecturers at IDU itself PEKERTI Applied Approach training is provided as a refresher program.

Another problem found is in the research aspect, so far the results of research conducted by lecturers are still normative and sometimes do not even touch the nature of the research itself. In terms of quantity, IDU's research results are satisfactory. However, the results of the study are based on quality standards that the research results of universities must strive to develop knowledge, in this case the science of defense, IDU is still far from expectations. In fact, the various results of IDU's research should be expected to provide benefits and input to IDU and stakeholders in the Ministry of Defense. Not to mention the phenomenon of the results of the implementation of research activities or research impressed to abort the obligation for lecturers to examine it without being accompanied by an increase in the quality of research so that it can benefit the community.

At the time of its establishment, IDU's Journal was still not accredited either at the national level or at a higher level. Then, the leadership efforts undertaken by increasing the rating of IDU's Journal so it can meet the requirements to publish nationally. Thus, at the moment IDU's Journal has been registered in the Ministry Research, Technology, and Higher Education of the Republic of Indonesia and has already obtained ISSN.

The final aspect in The Three Values of Higher Education, which is community service. In this aspect, IDU still needs to improve the quality of community service programs, where the existing programs have no evaluation so that the success of the program cannot be measured. In addition, community service carried out by IDU still has not touched crucial aspects. From the management aspect itself, the work mechanism between sub-work units in IDU has not run well due to lack of coordination. The organizational culture in IDU itself prioritizes military culture with a command system. This sometimes makes employees at IDU more focused on obedience to superiors, rather than focusing on the development of science and management of tertiary institutions.

Related to the method as an organizational guide, IDU also has another obstacle, namely the function of the chancellor at IDU also concurrently as ex-officio chairman of the senate. The chancellor and senate positions are supposed to be separated, because the senate should be a balance of organizational control and the chancellor himself functions as a supervisor.

\section{CONCLUSION AND RECOMMENDATION}

IDU has taken strategic steps deemed necessary for the advancement of IDU. IDU also has a strategic direction for implementing The Three Values of Higher Education in the context of education. The university's strategic achievements, such as those mentioned above, serve as a benchmark for the success of this organization. Although there is still much that needs to be addressed from the management system at IDU itself, such as monitoring and evaluation which must still be done through the EDOM system. IDU is considered as the thinktank of the Ministry of Defense which is expected to be able to provide input to the government on defense issues, meanwhile IDU has not been able to contribute directly to government policy. IDU's research results have not been used as material for consideration by relevant stakeholders. Research conducted seems to be normative and does not contribute significantly to society. However, IDU's Journal which is now registered in the Ministry Research, Technology, and Higher Education of the Republic of Indonesia and has already obtained ISSN can help IDU become a forum for IDU researchers and in the future the results of research that have been done can be taken into consideration by the Ministry of Defense. 
In the implementation of community service, every university, including IDU, has basic values that must be upheld when implementing community service programs. Ethical values and practices that are continuously emphasized by IDU are identity, nationalism, and integrity. These three values must be upheld by all IDU Academic Community members when they are conducting the Three Values of Higher Education. In addition, IDU has not been able to make an innovation related to community service.

\section{REFERENCES}

Abdulsyani. (1987). Manajemen Organisasi. Jakarta: Bina Aksara.

Abbas, Syahrizal. (2008). Manajemen Perguruan Tinggi, Jakarta: Kencana Prenadamedia Group.

Arikunto, Suharsimi. (2014). Prosedur Penelitian, Suatu Pendekatan Praktik. Cetakan Kelima belas. Jakarta: Rineka Cipta.

Bandur, Agustinus. (2016). Penelitian Kualitatif: Metodologi, Desain, dan Teknik Analisis Data dengan Nvivo 11 Plus. Jakarta: Mitra Wacana Media.

Budak, Fatih, Ahmed Kar. (2014). The Importance Of Strategic Leadership In Healthcare Management. International Refereed Academic Social Sciences Journal, Vol.15.

Emiroglu, Cagdas and Didem Ozer Caylan. (2014). The Importance Of Strategic Leadership For Port Management: A Delphi Research On Top Managers Of Turkish Private Port. Journal of Global Strategic Management, 8(2).

Griffin, Ricky W dalam Subekti Ridhotullah dan Mohammad Jauhar. (2015). Pengantar Manajemen.Jakarta: Prestasi Pustaka.

Hicks, Herbert G. (1972). The Management of Organizations: A System and Human Resoursces Approach.

Iskandar. (2009). Metodologi Penelitian Kualitatif: Aplikasi untuk Penelitian Pendidikan, Hukum, Ekonomi \& Manajemen, Sosial, Humaniora, Politik, Agama \& Filsafat. Jakarta: Gaung Persada.

Karyoto. (2016). Dasar-Dasar Manajemen: Teori, Definisi dan Konsep, Yogyakarta: Andi Offset.

Keller, George. (1986). Academic Strategy: The Top Management Revolution in American Higher Education. Baltimore: The Johns Hopkins University Press.

Kementerian Pendidikan dan Kebudayaan Republik Indonesia, Peraturan Menteri Pendidikan dan Kebudayaan RI Nomor 49 Tahun 2014 tentang Standar Nasional Pendidikan Tinggi.

Kementerian Pendidikan dan Kebudayaan Republik Indonesia, Peraturan Menteri Pendidikan dan Kebudayaan RI Nomor 45 Tahun 2012 tentang Organisasi dan Tata Kerja Universitas Pertahanan.

Kementerian Pendidikan dan Kebudayaan Republik Indonesia, Peraturan Menteri Pendidikan dan Kebudayaan RI Nomor 74 Tahun 2012 tentang Pengangkatan dan Pemberhentian Rektor Universitas Pertahanan

Manullang, M. (2015). Dasar-Dasar Manajemen. Yogyakarta: Gajah Mada University Press.

Miles, M \& Huberman, A. M. (2014). Qualitative Data Analysis: A Methods Sourcebook. Third Edition. USA: Sage Publication Inc.

Republik Indonesia, Undang-Undang Nomor 12 Tahun 2012 tentang Pendidikan Tinggi.

Riberu, J. (1987). Dasar-Dasar Kepemimpinan. Cetakan Ketiga: Jakarta: Pedoman Ilmu Jaya.

Rochmat Wahab, "Tata Kelola Perguruan Tinggi Yang Baik, Transparan, dan Akuntabel" PPT disampaikan dan dibahas pada kegiatan Seminar Nasional Anti Korupsi di Grahasaba, Universitas Gajah Mada, pada tanggal 25 Oktober 2016.

Salusu. (2015). Pengambilan Keputusan Stratejik Untuk Organisasi Publik dan Organisasi Nonprofit. Jakarta: Grasindo.

Siagian, P. (1980). Filsafat Administrasi. Jakarta: Gunung Agung.

Yukl, Gary A. (2009). Kepemimpinan Dalam Organisasi. Edisi Kelima. Alih Bahasa: Budi Supriyanto. Jakarta: PT Indeks. 